\title{
THE PREVENTION OF SOCIO-PATHOLOGICAL PHENOMENA AS THE SUBJECT OF INTEREST OF SOCIAL PEDAGOGY AND THE PROFESSION OF SOCIAL PEDAGOGUES - PRESENT NEEDS
}

\author{
Jolana Hroncová
}

\begin{abstract}
Social pedagogy in Europe, from its foundation to the present, has devoted its key attention to the prevention of socio-pathological phenomena in children and youth. The preventive dimension also belongs to the key competencies of school social pedagogues in Slovakia.
\end{abstract}

\section{Keywords}

prevention, socio-pathological phenomena, social pedagogy, social pedagogue, competence

\section{Preventive view of foreign social pedagogy and social work}

In Europe - mostly in Germany and Poland, the prevention of socio-pathological issues belonged to the core elements of teaching social pedagogy in its historical evolution. Social pedagogy in Germany was supposed to help in the fight against "social danger". In this context, Marburger (1979, p. 40) mentioned an idea of A. Diesterweg, who wrote in 1850: "City dregs are growing in numbers and represent a huge danger. They expand in an environment without general education, in which they do not care about the spiritual and moral backwardness of youth. Preventing this is a fundamental requirement". By turning attention to these marginalized groups of children, youth and adults as well as the removal of classroom learning approaches to education supported by its leading advocates (e.g. P. Natorp, A. Diesterweg and others), social pedagogy should have contributed to decrease social conflicts and unification of society. Representative of 
empiric movement of social pedagogy, P. Bergemann, turned his focus to social pedagogy in relation to the education, upbringing and the local social environment. He highlighted the prophylactic dimension to social pedagogy in two ways: on the one hand, in order to prevent deviant development of children in dysfunctional families, he emphasized the social control of public educational activities through the so-called family by means of the educational series. On the other hand, he asked for creation of diverse conditions and opportunities in education outside of the school classroom, so that positive spending of children's and youth' leisure time would have been provided.

Schilling (1999, p. 97) thought of social pedagogy as of an answer to the problems of modern society and as a help for eliminate the emerging risks. Social pedagogy, as means of caring for youth and a systematic upbringing, was understood as a replacement of family services needed for the prevention of youth' moral damage. J. Schilling also states that in the past social pedagogy was known for its "negative" model, which resulted in its focus on the secondary and tertiary prevention. It was fulfilling the tasks of a "social firefighter", "nation's repairman", "deficit repair shop", or it was identified as "pedagogy of emergency states". According to J. Schilling, social pedagogy should be "positive". He also thinks of it as a tertiary training and educational institution centred on social help for children and youth. The focus of its subject, Schilling (1999, p. 99) speaks of its primary prevention as follows: "Social pedagogy is a public (state or private) care for children and youth, meaning to protect poor children and young people from neglect by means of preventive and curative measures". Another representative of the German social pedagogy, H. Schwalb, also declares that students of social pedagogy are studying to provide education, counselling and re-socialization works, further training, planning and organization works with children, youth and families in socio-pedagogical facilities, which are translated into "activities connected with socialization, prevention, and removal of de-socialization" (Kraus et al., 2001, p. 44).

The preventive aspect of social pedagogy is strongly depicted in the Polish social pedagogy too. Terms "prophylaxis" and "compensation" introduced to Polish social pedagogy by its founder H. Radlinska, belong to the "unshakeable" concept of terminology and the Polish social pedagogy focus. Prophylaxis (i.e. prevention) is activity connected with neutralization of influences of factors causing potential danger. Prophylactic activity can be developed in two ways: by the reduction of the activity leading to potential danger, or by stimulation of the positive activities of educating outside of the schools classroom (Wroczyński, 1968, p. 65).

The Czech representative of social pedagogy, Kraus et al. (2001, p. 44), defines social pedagogue as an expert on educational work in two areas:

a) direct social education with use of prophylaxis or compensation,

b) managerial social education in institutions, i.e. organizational, compensatory, methodical, educational (design of programmes, projects management and so on). Kraus considers the main functions of social pedagogue to be integrational activities (concerning people in crisis life situations with the need of help) and developing activities, assuring desirable development of personality in terms of correct lifestyle and effective 
spending of leisure time, which also involves prevention and concerns all population, primarily children and youth (Kraus et al., 2001, p. 44-45). B. Kraus also stresses the issue of prevention in his publication Základy sociální pedagogiky (2008).

\section{Preventive socio-educational work in Slovak schools - participation of social pedagogues and social workers in it}

The growth of socio-pathological phenomena in Slovakia and other post-communist countries after 1989 sparked the need for social development of helping professions like "social pedagogy" and "social work", and their participation in prevention and solving of those serious problems. Due to the fact that they constantly reduced the minimum age limit for the incidents of deviant behaviour of children and adolescents, it became necessary to intensify the prevention of socio-pathological phenomena, particularly primary prevention in the school environment, rather than the behavioural disorders manifest. It is because of this, and also because of the family's failure to frequently create the base for the children's "immunization" against creation of socio-pathological phenomena, that the professionalization of prevention in school environment is necessary. Despite family being a primary educational and socialization factor, it represents a non-professional educational institution, although parents often symbolize negative educational and human pattenrs. Many empirical researches support this fact (in Hroncová \& Kraus et al., 2006; in Matoušek \& Kroftová, 1998, 2003) by highlighting significant impact of dysfunctionality of family on the creation of socio-pathological phenomena of children and youth. Particularly for criminality, drug addiction, bullying, suicide rate and so on, the dominant criminogenic factor is the dysfunctional family. Therefore, it is necessary that school would compensate for the lack of family environment and pay greater attention to pupils from endangered and socially disadvantaged environment. Compensatory and preventive function in school should be conducted on a professional level, which has been emphasized by many European and national documents focused on the prevention of socio-pathological phenomena. For example, the Slovak "Stratégia prevencie kriminality na obdobie 2007-2010" (Crime prevention strategy 2007-2010), as well as the current school law "Act No. 245/2008 Coll. On Training and Education and Act No. 317/2009 Coll. On Pedagogical Staff and Specialists", which are not only emphasizing the professionalization of prevention, but also defines the function of social pedagogue as a professional employee of schools and educational institutions in the field of prevention and other related activities.

On 9 September 2008, the law Act No. 245/2008 Coll. On Training and Education came into law and in its $\S 130$ it specifies the system of educational counselling and prevention in schools and school facilities. This law assigns social pedagogue to other sectors of educational consultancy and a prevention system cooperating with family, school, school facilities, employer, public authorities and civil society associations. However, according to this law, the main function of a social pedagogue remains in school system from nursery 
schools to secondary schools - $\S 27$, Article 2 lett. a) to f), in specialized educational facilities and school facilities (boarding schools $\S 117$ Article 5).

Another legislative norm specifying the profession of social pedagogue is law Act No. 317/2009 Coll. On Pedagogical Staff and Specialists. According to this law, a social pedagogue is categorized as a professional employee ( $\S 19)$ and $\S 24$ defines his profession as follows: "Social pedagogue performs professional activities in terms of prevention, intervention and providing consultancy mostly for children and pupils endangered by socio-pathological phenomena, coming from socially disadvantaged environment, drug addicts or children and pupils disadvantaged in other ways, their legal representatives and pedagogic employees of schools and schooling facilities. The social pedagogue fulfils the role of social education, the promotion of social, ethical behaviour, social-pedagogic diagnostics of environment and relationships, social-pedagogic counselling, prevention of socio-pathological phenomena and behavioural re-education. He performs expert and educational activities". Profession of social pedagogue in school can be carried out under given legislature by a graduate with master's degree from "social pedagogy" or "social work".

At present, two legal norms allow social pedagogues to work as specialized employees in schools, from nursery to secondary schools. School practice, however, makes only small use of these possibilities, mostly because of lacking of financial resources. The report called "Správa o stave školstva na Slovensku a o systémových krokoch na podporu jej d'alšieho rozvoja" (A report on the state of education in Slovakia and systemic steps to be taken for its future development) published by Ministry of Education, Science, Research and Sport of Slovak Republic in 2013 states that "I consider jeopardizing the safety of children and pupils and the teaching of pedagogical and non-pedagogical school staff (pupil bullying, assaulting of teachers by pupils or their legal representatives) to be a serious problem of education". It also points out "increase in the consumption of alcohol and other drugs by pupils of lower age groups" (p. 50-51). To solve these and other problems it is necessary "to increase the amount of employees specialized in prevention". School legislature marks this employee as a social pedagogue. This report shows the possible expectancy of future improvement in finding employment of social pedagogues in schools, since pupils' deviant behaviour is increasing.

Despite the low rate of social pedagogues in Slovak schools, it is positive that social pedagogues in Slovak schools are already legally established as specialist employees. This is not true for Czech Republic and Poland, although Poland's social pedagogy has a much longer tradition than the Slovak one.

\section{Prevention of socio-pathological phenomena in the "Banská Bystrica School of Social Pedagogy"}

The "Banská Bystrica School of Social Pedagogy" is considered to be one of the strongest and mostly advanced workplaces in Slovakia, because it helps to develop 
social pedagogy not only in theory, but also in scientific research, experimental, pedagogical and methodological level. Many teachers from the Department of Pedagogy on UMB's Faculty of Education, are cooperating with foreign universities on development of theory and practice of social pedagogy, as well as on solving research tasks, have been studying social pedagogy for a long time. They are teachers and include J. Hroncová, I. Emmerová, M. Niklová, K. Cimprichová-Gežová and others. At the same time, J. Hroncová is a head guarantor of the Master's degree study programme "Social Pedagogy", which is currently a unique study programme, since there is no other like that in Slovakia. It has been developing in UMB's Faculty of Education since the academic year 1994/95.

Despite the fact that it hasn't got a long history, the "Banská Bystrica School of Social Pedagogy", developing in UMB's Faculty of Education's Department of Pedagogy, is known for its rich publication activities and conference entries not only at home, but also abroad. Most of these publications are focused on social pedagogy problems and prevention of socio-pathological phenomena. This is also one of the crucial issues in the subject of social pedagogy, as an educational discipline. It also belongs to the dominant fields of social pedagogy study programme, implemented by UMB's Faculty of Education's Department of Pedagogy. Those of the most important publications concerning social pedagogy and prevention of social pathology are: Hroncová, J. - Hudecová, A. - Matulayová, T.: "Sociálna pedagogika a sociálna práca" (Social pedagogy and social work; 2000, 2001), Hroncová, J. - Emmerová, I.: "Sociálna pedagogika" (Social pedagogy, 2004).

J. Hroncová is the leading author of numerous monographs. Many of them are focused on social pedagogy and prevention of social pathology: Hroncová, J. - Kraus, B. et al.: "Sociálna patológia pre sociálnych pracovníkov a pedagógov" (Social Pathology for Social Workers and Social Pedagogues, 2006), Hroncová, J. - Walancik, M. et al.: "Vybrané problémy slovenskej a pol'skej sociálnej pedagogiky" (Selected Problems of Slovak and Polish Social Pedagogy, 2009), Hroncová, J. - Emmerová, I. et al.: "Sociálna pedagogika - vývoj a súčasný stav" (Social Pedagogy - Development and Current State, 2009), Hroncová, J. - Emmerová, I. - Walancik, M. et al.: "Pedagogika sociálnej starostlivosti" (Pedagogy of Social Treatment, 2011), Hroncová, J. - Emmerová, I. et al.: "Sociálny pedagóg v škole" (Social Pedagogue in School, 2012), Hroncová, J. et al.: "Sociálna pedagogika na Slovensku" (Social Pedagogy in Slovakia, 2012), Hroncová, J. - Emmerová, I. - Hronec, M.: "Sociálna patológia pre sociálnych pedagógov" (Social Pathology for Social Pedagogues, 2014), Hroncová, J. - Emmerová, I. et al.: "Sociálny pedagóg v škole v teoretickej reflexii a praxi" (Social Pedagogue in School in Theoretical Reflection and Practice, 2015), and others.

I. Emmerová is also writing about and is dedicated to the prevention of socio-pathological phenomena in the following works: "Prevencia sociálnopatologických javov $v$ školskom prostredí" (Prevention of Socio-Pathological Phenomena in School Environment, 2007), "Poruchy správania u žiakov základných a stredných škôl - ich prevencia a riešenie" (Elementary and Secondary School Students' Behaviour Disorders - Their Prevention And Solutions, 2008), where she discusses the work of social pedagogues too, "Aktuálne 
otázky prevencie problémového správania u žiakov v školskom prostredí" (Current Questions on Prevention of Problem Behaviour of Students in School Environment, 2011). One of her most recent works is the book "Preventívna a sociálno-výchovná práca s problémovými detimi a mládežou" (Preventive And Socio-Educational Work With Problem Children And Youth, 2012).

"Banská Bystrica School of Social Pedagogy" also intensively develops social pedagogy in terms of science and research thanks to projects of international cooperation, and mainly in the context of national projects VEGA and KEGA. Science and research activities of "Banská Bystrica School of Social Pedagogy" is mostly focused on the prevention of children's and youth' socio-pathological phenomena and problems with use of social pedagogues in practice. In 2004 and 2005 we were working on completing the international research task "Sociálno-patologické javy vo vysokoškolskej príprave sociálnych pracovníkov a sociálnych pedagógov" (Socio-Pathological Phenomena in University Preparation of Social Workers and Social Pedagogues) under the terms of the deal between the governments of Czech Republic and Slovakia for 2004-2005 No. 119, responsible researcher of which was J. Hroncová for the Slovak Republic and B. Kraus for the Czech Republic. Teachers at UMB's Department of Social Work also took part.

In 2007 and 2009, the department was completing the research project VEGA No. 1/4527/07 called "Profesijné kompetencie sociálnych pedagógov v oblasti prevencie sociálnej patológie u detí a mládeže" (Professional Competences of Social Pedagogues in Prevention of Social Pathology of Children and Youth, prof. PhDr. J. Hroncová, PhD. as the responsible researcher), in which researchers like I. Emmerová, M. Niklová, L. Kamarášová, M. Hronec and others took part.

Other projects like VEGA, especially VEGA No. 1/0303/11, called "Spolupráca inštitúcií verejnej správy so školami v oblasti prevencie sociálno-patologických javov s osobitným zretel'om na uplatnenie sociálnych pedagógov v Banskobystrickom kraji" (Cooperation of Public Administration Institutions and Schools in Prevention of Socio-Pathological Phenomena with Regard to Social Pedagogues' Employment in Banská Bystrica Region, prof. PhDr. J. Hroncová, PhD. as the responsible researcher), and project VEGA No. 1/0168/12, called "Profesionalizácia prevencie sociálnopatologických javov v školskom prostredí v SR z aspektu profesie sociálneho pedagóga - súčasný stav, problémy a komparácia so zahraničím" (Professionalization of Prevention of Socio-Pathological Phenomena in School Environment in Slovak Republic from the Point of View of Social Pedagogue - Current State, Problems and Comparison to Foreign Countries, prof. PhDr. I. Emmerová, PhD. as the responsible solver), were focusing on the profession of social pedagogue.

Apart from publications in journals and monographs, the research results on social pedagogy and prevention of socio-pathological phenomena have also been presented at international conferences like SOCIALIA conferences taking place at UMB's Faculty of Education under guarantee of J. Hroncová and A. Hudecová. This includes SOCIALIA 2007 called "Prevencia sociálno-patologických javov u detí, mládeže a dospelých" (Prevention of Socio-Pathological Phenomena of Children, Youth and Adults), SOCIALIA 2009, 
focused on "Profesijné kompetencie sociálnych pedagógov a sociálnych pracovníkov $\checkmark$ teórii a $v$ praxi v SR a v iných krajinách Európskej únie" (Professional competences of social pedagogues and social workers in theory and practice in Slovakia and other countries of the European Union), and SOCIALIA 2011, called "Participácia inštitúcií verejnej správy a pomáhajúcich profesií na prevencii sociálno-patologických javov u detí, mládeže a dospelých v Slovenskej republike a v iných krajinách Európskej únie" (Participation of Public Administration Institutions and Helping Professions in Prevention of Socio-Pathological Phenomena of Children, Youth and Adults in Slovak Republic and Other Countries of the European Union). Most of all, these conferences presented results of research projects of "Banská Bystrica School of Social Pedagogy" representatives.

Except VEGA projects, we are also working on many other projects of KEGA, e.g. KEGA No. 028UMB-4/2012: "Preventívna sociálno-výchovná práca na základných a stredných školách z aspektu funkcie sociálneho pedagóga" (Preventive Socio-Educational Work in Elementary and Secondary Schools from the Point of View of Function of Social Pedagogue). In addition to the contributions referred to in the professional journals, one of the more extensive publications about this task is also monograph by Hroncová, J. et al.: "Sociálna pedagogika na Slovensku (História a súčasnost')" (Social Pedagogy in Slovakia (History and Present), 2012) and anthology "Sociálny pedagóg v škole" (Social Pedagogue in School, 2012), presenting performances of famous Slovak, Czech and Polish social pedagogues and their experience from Slovak schools and school facilities. The first event in Slovakia, focused on schooling, social and educational work of social pedagogue, was at the international professional seminar "Sociálny pedagóg $v$ škole" (Social Pedagogue in School). It has laid the foundations of exchange of theoretical, methodical and practical knowledge and skills in school work of social pedagogues. It has also started a mutual cooperation of UMB's Faculty of Education, the only Slovak school workplace with Master study programme "Social Pedagogy", with foreign university institutions and social pedagogues in practice.

On that account, "Banská Bystrica School of Social Pedagogy" is and will be focusing its theory, research and methodology on school socio-pedagogical work and social pedagogue's place in school. One of its dominant features is also primary and secondary prevention of socio-pathological phenomena. Even though this employment has already been legally well-established in Slovakia since 2008, there is still no professional standard: social pedagogue available, although even "Banská Bystrica School of Social Pedagogy" joined its preparation. We are also taking part in the creation of still lacking methodical materials. The first methodical handbook we offered to social pedagogues was "Metodická príručka pre sociálnych pedagógov a koordinátorov prevencie pod názvom Preventívna sociálno-výchovná činnost́ v škole" (Methodical Handbook for Social Pedagogues and Coordinators of Prevention Called Preventive Socio-Upbringing Activity in School, 2013), processed under the guidance of author Hroncová, J. - Emmerová, I. et al. These authors also created and developed the project for the updating the training and education for school social pedagogues' career progression or advancement, accredited by Ministry of Education, Science, Research and Sport of Slovak Republic at the beginning of 2016. 
Every year we present the results of "Banská Bystrica School of Social Pedagogy" at the international conferences Socialia. We also present them at the "Sociálna pedagogika $\checkmark$ strednej Európe" (Social Pedagogy in Central Europe) conferences, organized by Interdisciplinary Studies Institute (IMS) in Brno. UMB's Department of Pedagogy is a traditional cosponsor of the aforementioned conferences and annually publishes "Zborník vedeckovýskumných prác Katedry pedagogiky" (Anthology on Scientific Works of Pedagogy Department, J. Hroncová and I. Emmerová as editors), presenting results of the researched projects. This anthology was for the first time published in 2005.

The results of socio-pedagogical research and theory are published in the following journals, too: The New Educational Review, Pedagogická orientace (Pedagogic Orientation), Sociálna prevencia (Social Prevention), Prevencia (Prevention), Mládež a spoločnost'(Youth and Society), Vychovávatel'(Educator), and in other specialized professional journals.

"Banská Bystrica School of Social Pedagogy" is a co-worker of the university institutions in Slovakia and abroad, e.g. in Czech Republic and Poland, where the universities are preparing social pedagogues and work with theoretical and methodological problems of social pedagogy.

\section{Conclusion}

"Banská Bystrica School of Social Pedagogy" is a successor of "Balážova School of Social Pedagogy". Its founder, leading representative and author of this paper, was among the first internal scientific aspirants of prof. O. Baláž, the creator of Slovak social pedagogy established in 1970s at the Experimental Pedagogy Institute SAV in Bratislava.

Theoretical, scientific, research, publishing and pedagogical activities of "Banská Bystrica School of Social Pedagogy" representatives have made a great contribution to the overall development of Slovak social pedagogy. "Banská Bystrica School of Social Pedagogy" is a workplace looking at social pedagogy from pedagogical, scientific and publishing point of view. Its work was also awarded during the complex accreditation by The Accreditation Commission of Slovak Republic, which said that "the workplace has demonstrated international excellence in their given field". Although social pedagogy hasn't had a long history in Slovakia, we can say that at the present it is a rather developed branch. Unfortunately, institutionally and personally it has a weak university representation. However, since its creation, it's been intensively developing mostly thanks to national and international cooperation.

\section{References}

Hroncová, J., \& Kraus, B. et al. (2006). Sociálna patológia pre sociálnych pracovníkov a pedagógov [Social Pathology for Social Workers and Social Pedagogues]. Banská Bystrica: Faculty of Education, Matej Bel University. 
Hroncová, J., \& Staňová, J. et al. (2007). Život a dielo prof. Ondreja Baláža [The Life and Works of Professor Ondrej Baláž]. Banská Bystrica: Faculty of Education, Matej Bel University.

Hroncová, J., Emmerová, I., \& Kraus, B. et al. (2008). K dejinám sociálnej pedagogiky $\checkmark$ Európe [On the History of Social Pedagogy in Europe]. Ústí nad Labem: Faculty of Education, Jan Evangelista Purkyně University.

Hroncová, J., \& Emmerová, I. et al. (2009). Sociálna pedagogika. Vývoj a súčasný stav [Social Pedagogy. Development and Current State]. Banská Bystrica: Faculty of Education, Matej Bel University.

Hroncová, J., \& Walancik, M. et al. (2009). Vybrané problémy slovenskej a pol'skej sociálnej pedagogiky [Selected Problems of Slovak and Polish Social Pedagogy]. Banská Bystrica: Faculty of Education, Matej Bel University.

Hroncová, J. et al. (2012). Sociálna pedagogika na Slovensku: (história a súčasnost) [Social Pedagogy in Slovakia: (History and Present)]. Banská Bystrica: Faculty of Education, Matej Bel University.

Hroncová, J., \& Emmerová, I. et al. (2012). Sociálny pedagóg v škole [Social Pedagogue in School]. Banská Bystrica: Faculty of Education, Matej Bel University.

Hronec, M. (2010). Ekonomické aspekty výchovy a vzdelávania [Economic Aspects of Upbringing and Education]. Banská Bystrica: Faculty of Economics, Matej Bel University.

Kraus, B., \& Poláčková, V. et al. (2001). Člověk-prostředí-výchova [Human - Environment - Education]. Brno: Paido.

Kraus, B. (2008). Základy sociální pedagogiky [Basics of Social Pedagogy]. Prague: Portál.

Marburger, H. (1979). Entwicklung und Konzepte der Sozialpädagogik. München: Juventa.

Matoušek, O., \& Kroftová, A. (1998). Mládež a delikvence [The Youth and Delinquency]. Prague: Portál.

Paučíková, D. (2011). Inštitucionálne a legislatívne zabezpečenie sociálno-výchovnej starostlivosti v súčasnosti a jej diferenciácia [Current Institutional and Legislative Security of Socio-Educational Care and Its Diferentiation]. In J. Hroncová, I. Emmerová, \& M. Walancik et al., Pedagogika sociálnej starostlivosti [Pedagogy of Social Treatment]. Banská Bystrica: Faculty of Education, Matej Bel University. 
Schilling, J. (1999). Sociálna práca. Hlavné smery vývoja sociálnej pedagogiky a sociálnej práce [Social Work. Main Directions of the Development of Social Pedagogy and Social Work]. Trnava: University of Trnava.

Wroczyński, R. (1968). Sociálna pedagogika [Social Pedagogy]. Bratislava: SPN.

\section{Author}

prof. PhDr. Jolana Hroncová, PhD.

Faculty of Education, Matej Bel University

Department of Pedagogy

Ružová 13, 97411 Banská Bystrica, Slovak Republic

jolana.hroncova@umb.sk 